
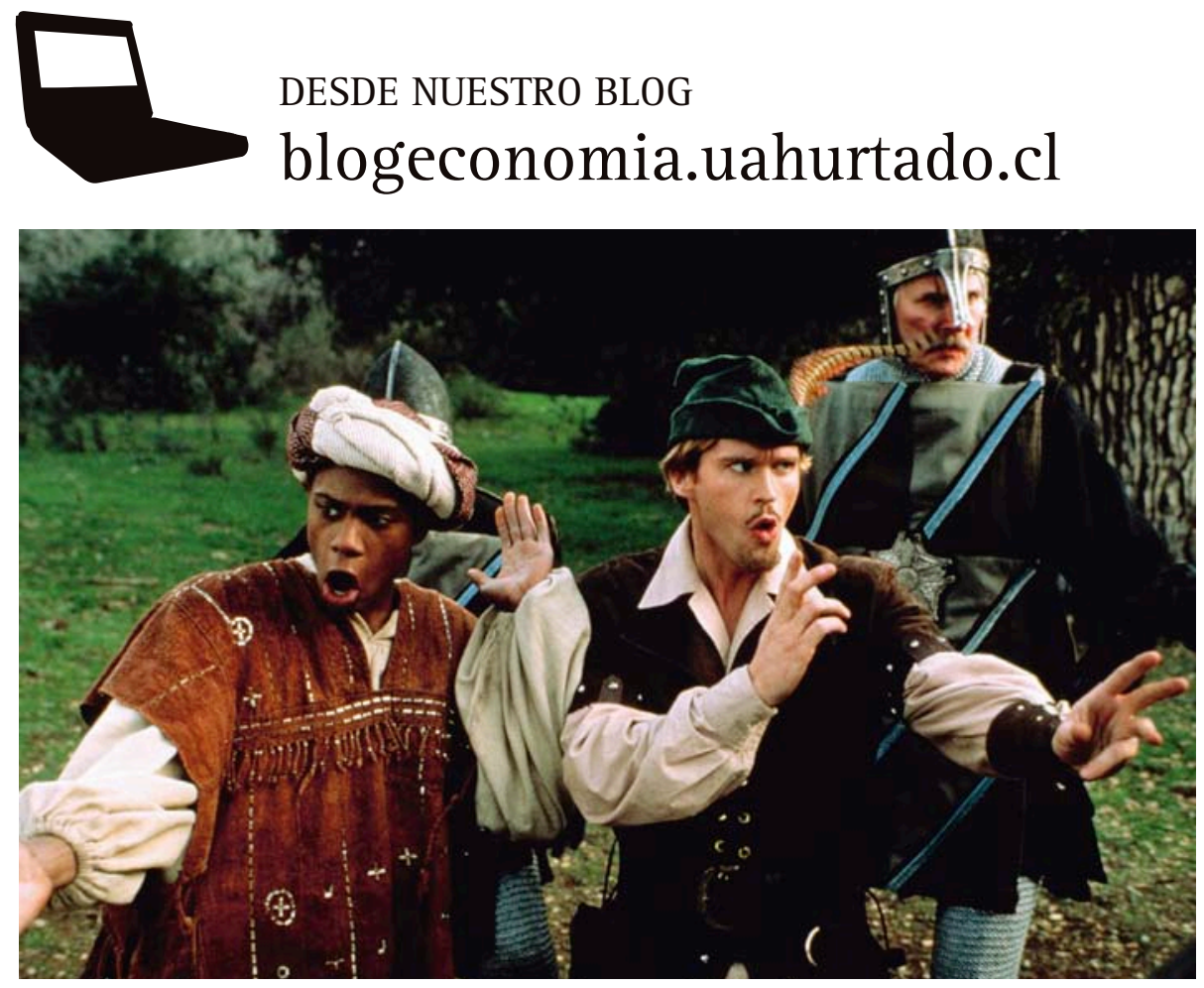

\title{
Robin Hood está perdido
}

Por Claudia Sanhueza*

Al diseñar programas sociales, una de las principales características que los economistas consideramos es el grado de focalización. Es decir, que las políticas sociales lleguen a quienes tengan que llegar. Para eso, levantamos información de las personas (mediante la Ficha de Protección Social, por ejemplo) y determinamos índices de vulnerabilidad para identificar a quienes más lo necesitan.

Estas operaciones en apariencia simples toman bastante de nuestro tiempo, especialmente en Chile, y qué bueno que sea así. Hay autores que destacan esto. Un paper reciente de Lindert, Skuofias y Shapiro (2005) puntualiza que en Chile las transferencias monetarias son de un potencial importante impacto distributivo. De hecho, es recomendable aumentarlas, porque dado el nivel de ingreso del país, gastamos poco en ellas. Sin embargo, del otro lado de la moneda... ¿qué está pasando? Porque cuando uno habla de políticas redistributivas no solamente debe observar lo que le llega a las personas, sino lo que les saca, y a quienes.

La principal fuente de financiamiento del Estado en Chile es mediante ingresos tributarios. La idea de tener políticas sociales redistributivas es: saco a los que más tienen para redistribuir a los que menos tienen.

Y aunque en Chile Robin Hood efectivamente llega más a los que menos tienen, parece que se olvida de visitar a quienes poseen más. En simple: ¿los que más tienen son los que financian estas políticas redistributivas? La última evidencia disponible dice: NO (Engel, Galetovic y Raddatz, 1998). Los ingresos tributarios provienen de dos fuentes principalmente: IVA e Impuesto a la Renta. El IVA es regresivo: saca más ingreso a los más pobres. El impuesto a la renta es progresivo. Sin embargo, la importancia total del IVA es más fuerte y la existencia de variados tratamientos especiales en el impuesto a la renta hace que en su totalidad, la recaudación tributaria en Chile sea regresiva (Engel, Galetovic y Raddatz, 1998 y Agostini 2008, 2009). Esto es, la distribución empeora levemente después de impuestos: los más pobres financian una mayor parte de las politicas sociales, en términos porcentuales a sus ingresos, que los más ricos: Robin Hood al revés.

* Profesora Facultad de Economía y Negocios UAH. Ph. D. en Economía, Universidad de Cambridge, Inglaterra.

\section{¿CUÁNTO VALE UN PESO \\ CHILENO EN EL MUNDO?}

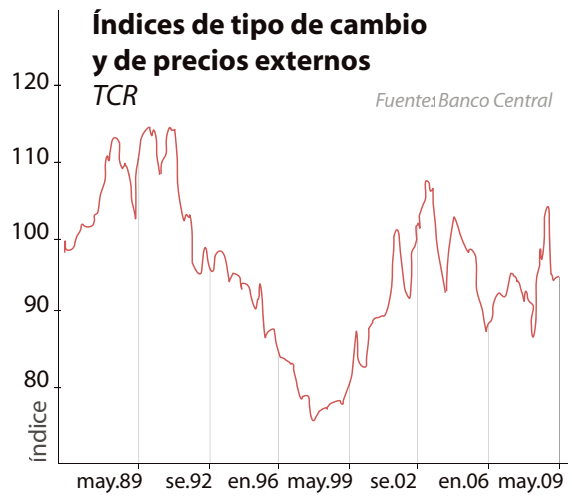

\section{Por Juan Foxley*}

El TC (tipo de cambio) es un precio clave. Según su valor en pesos chilenos, será objeto de queja o de silencio por exportadores y sustituidores de importaciones.

Pero la medida más pertinente para comparaciones de competitividad es el tipo de cambio real. Se define como el TC observado para las monedas de los países "socios", multiplicado por el cuociente entre la inflación externa relevante -es decir, el IPM ponderado por países, pero sin cobre ni petróleo- y el IPC. El TC real es cerca de $25 \%$ mayor al mínimo alcanzado en octubre del 97 y $20 \%$ mayor que enero de 1999, cuando se crea el euro.

El valor de la paridad (US dólar / euro) condiciona en buena parte la competitividad que Chile ve reflejada en su TC Real.

Desde su creación, el euro se ha apreciado $19 \%$ contra el US dólar mientras el yen le ha ganado $16 \%$ a la moneda estadounidense. Fortalecidos, el euro y el yen han ayudado a mejorar la competitividad de Chile en el mundo durante los dos últimos gobiernos, paliando en parte el efecto negativo de la expansión del gasto fiscal sobre el precio del US dólar en pesos.

* Director Diplomado en Finanzas UAH. 